\title{
DOES BLACK LOCUST PERFORMS IN ANY FOREST SITES?
}

\author{
Cornelia Buzatu-Goanță ${ }^{1, *}$, Ana-Maria Angela Dumitraşcu ${ }^{2}$ \\ ${ }^{1}$ Banat's University of Agricultural Sciences and Veterinary Medicine "King Michael I of Romania" \\ from Timisoara, Romania \\ ${ }^{2}$ Corcova Forest District, Mehedinti County Branch of National Forest Administration-ROMSILVA, Romania
}

\begin{abstract}
Black locust is a non-native tree species introduced in Romania like an ornamental tree around 1750. One hundred years later the first plantation was established. The fast-growing capacity and apparently low ecological requirements made black locust so attractive that it was established not only in suitable sites but also in unsuitable sites, in these last cases with unsatisfactory results. Examples are stands with black locust from Razboinicu Working Circle, Forest District Strehaia. Data from management plans were analyzed for pure black locust stands and mixtures in terms of age, composition, regeneration pathway, and yield. More than $70 \%$ are pure stands; others are mixtures with oaks (Turkey and Hungarian oak) and other tree species like European hornbeam, field maple, European aspen, European ash, field elm. Stands older than 20 years are usually mixtures with a small percent of black locust. There are different regeneration pathways, stump stools, and root suckers in case of old stands, plantation for some the younger stands. The productivity is lower than the average national yield table for similar pathway.
\end{abstract}

Keywords: productivity, regeneration pathway, Robinia pseudoacacia, stands composition.

\section{INTRODUCTION}

Black locust (Robinia pseudoacacia L.) is a non-native tree species originary from North America. In Romania, black locust found a second homeland. It was introduced in Romania around 1750 like an ornamental tree, then 100 years later (1852 - Băileşti Oltenia), plantations with black locust were established (Drăcea, 1928).

The wood of black locust is hard, heavy, very dense, and moisture resistant. It has a lot of utilization like poles, props, tool tails, timber, parquet, firewood etc.

The best black locust stands regenerated by seedling produce, at the age of $20,15-17 \mathrm{~cm} \mathrm{yr}^{-1} \mathrm{ha}^{-1}$. At the same time, stands regenerated vegetatively produce $13.4 \mathrm{~cm} \mathrm{y}^{-1} \mathrm{ha}^{-1}$ (Stănescu, 1979).

It is an important melliferous tree species and it is also important for their protective role (sandy dune fixation, degraded land restoration). In the last decades, black locust was used for biomass energy (Rédei and Veperdi, 2009; Rédei et al.2011). It is a fast-growing tree species with a great capacity of vegetative reproduction by stool stumps and root suckers. These characteristics are problematic, from the viewpoint of nature conservation (Vitková et al. 2018).

In Romania, black locust covers 250,000 ha (Enescu and Dănescu, 2015), the biggest area with this tree species are located on continental dunes, in the south of Oltenia, the south of Moldova and the north-west of Romania (Negulescu and Săvulescu 1965; Haralamb, 1967; Stănescu, 1979). 


\section{Current Trends in Natural Sciences}

Vol. 9, Issue 17, pp. 126-131, 2020

https://doi.org/10.47068/ctns.2020.v9i17.014

Current Trends in Natural Sciences (on-line)

ISSN: 2284-953X

Current Trends in Natural Sciences (CD-Rom)

ISSN: 2284-9521

ISSN-L: 2284-9521

ISSN-L: 2284-9521

Well-aerated soils, rich in nutrients, without too much moisture and not compacted are required by black locust for good results in terms of growing capacity. The temperature required is between 9$11^{\circ} \mathrm{C}$ and the minimum annual rainfall 400-500 mm (Stănescu, 1979).

The fast-growing capacity and apparently low ecological requirements made black locust so attractive that it was established even in unsuitable sites, with unsatisfactory results (Haralamb, 1967). It happens in Razboinicu Working Circle, where black locust was established in oaks sites (especially Turkey oak - Quercus cerris L. and Hungarian oak - Quercus frainetto Ten.) with compacted soils.

This paper aims to highlight the productive capacity of black locust in unsuitable sites.

\section{MATERIALS AND METHODS}

Researches were made in Razboinicu Working Circle, Strehaia Forest District, Mehedinți County Branch of National Forest Administration-ROMSILVA (figure 1).

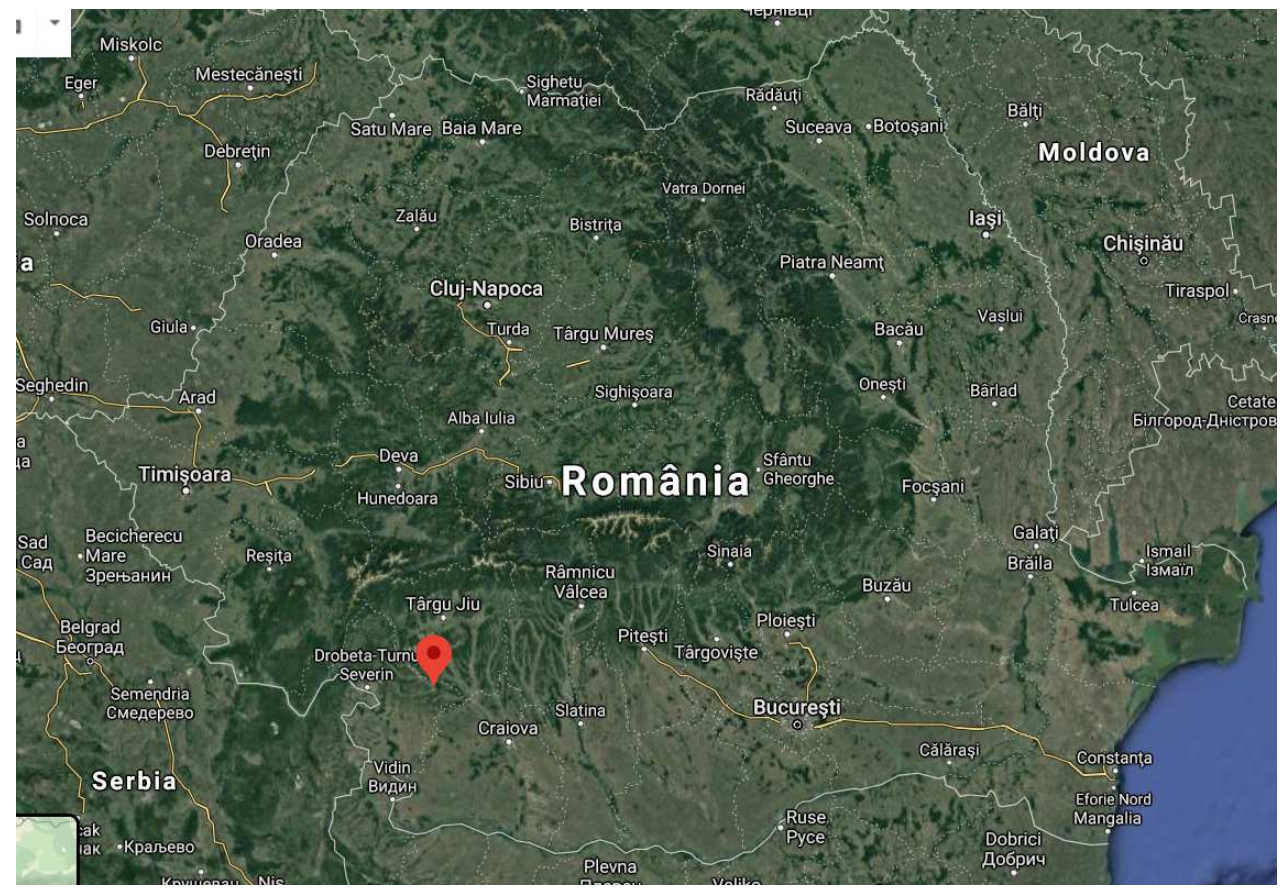

Figure 1. Location of Razboinicu Working Circle (https://www.google.ro/maps/)

Geographically, stands are located in the north part of Bălăcița Piedmont, average elevation $230 \mathrm{~m}$ $(100-300 \mathrm{~m})$. It is a hilly area with a high relief fragmentation and energy relief. The valleys are sometimes narrow, sometimes wide, with terraces and repeated slopes, attacked by torrents and landslides. The climate is continental with an annual rainfall of over $600 \mathrm{~mm}$, with a maximum in early summer and average annual temperatures of $10-11^{\circ} \mathrm{C}$. Different soil types have been identified in that area: preluvosol and luvisol, with the formation of eluvial and illuvial horizons like a result of clay migration and aluviosol with a high sand percentage but low fertility.

Characteristic for this area are oaks (Sessile oak - Quercus petraea (Matt.) Liebl., Turkey oak Quercus cerris L.) and mixed forests hill sites, medium or poor quality (Anonymous, 2008).

Dates from Plan Management about black locust stands and mixtures regarding age, composition, regeneration pathway, and volume were analyzed. 


\section{Current Trends in Natural Sciences}

Vol. 9, Issue 17, pp. 126-131, 2020

https://doi.org/10.47068/ctns.2020.v9i17.014

Current Trends in Natural Sciences (on-line)

ISSN: 2284-953X

Current Trends in Natural Sciences (CD-Rom)

ISSN: 2284-9521

ISSN-L: 2284-9521

ISSN-L: 2284-9521

\section{RESULTS AND DISCUSSIONS}

114 ha are occupied by black locust stands or mixtures that mean $3 \%$ of working circle area. The black locust effective area (according to density) is 74.4 ha.

Black locust was established in this area to 100-300 elevation, in hilly oaks (Sessile oak - Quercus petraea (Matt.) Liebl., Turkey oak - Quercus cerris L., Hungarian oak - Quercus frainetto Ten.) sites and hilly with European beech (Fagus sylvatica L.) sites. $81 \%$ are medium quality sites, proper for native Romanian oaks (European oak -Quercus robur L., sessile oak - Quercus petraea (Matt.) Liebl., Hungarian oak - Quercus frainetto Ten., and Turkey oak - Quercus cerris L.,), for European beach (Fagus sylvatica L.) in some area and other broadleaves tree species like ash (Fraxinus excelsior L.), linden (Tilia sp.) European hornbeam (Carpinus betulus L.), cherry (Prunus avium L.), maples (Acer sp.). 19\% are poor quality sites for tree species. According to the soils, $88 \%$ of stands are found on luvosols, very strongly acid to slightly acid on topsoil and moderately acid in the subsurface, a low troficity and a different texture on soil profile.

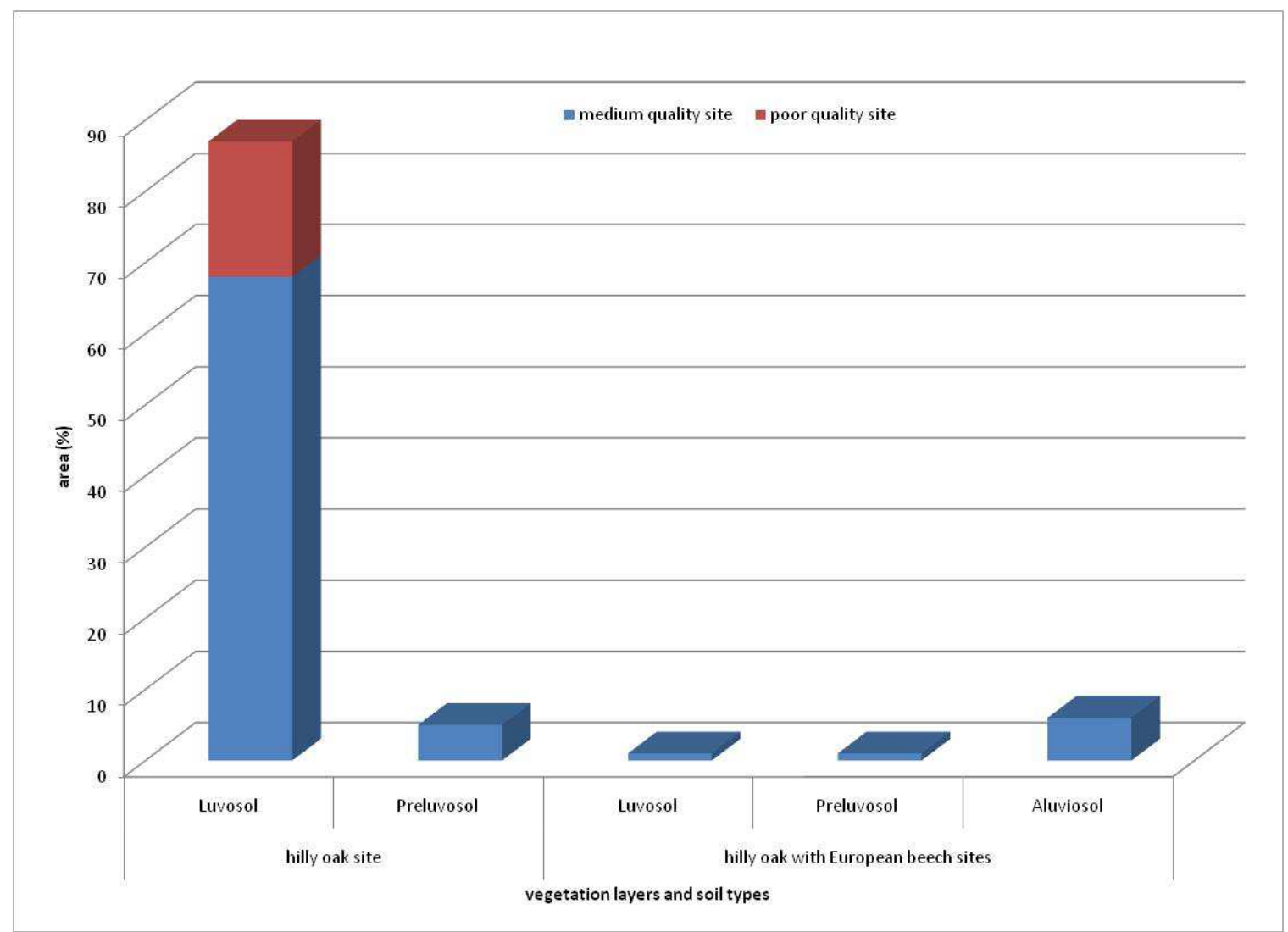

Figure 2. Black locust distribution according to soil types and vegetation layers

The others are found on preluvosols (6\%) with a high percent of clay (a limitative factor) and aluviosols (figure 2).

In our country, black locust stands are usually pure stands (Enescu and Dănescu, 2015; Stănescu, 1979) but in this area, only $72 \%$ are pure stand (figure 3), the others are mixtures with a different percent of oaks and European hornbeam (Carpinus betulus L.), field maple (Acer campestre L.), common aspen (Populus tremula L.), European ash (Fraxinus excelsior L.) and field elm (Ulmus minor L.). An interesting distribution is according to stands composition. Mixed stands with a lower 


\section{Current Trends in Natural Sciences}

Vol. 9, Issue 17, pp. 126-131, 2020

https://doi.org/10.47068/ctns.2020.v9i17.014

Current Trends in Natural Sciences (on-line)

ISSN: 2284-953X

Current Trends in Natural Sciences (CD-Rom)

ISSN: 2284-9521

ISSN-L: 2284-9521

ISSN-L: 2284-9521

percentage of black locust are older than 20 years. Only a small percent can be found in first age class.

Depending on stand composition and regeneration pathway black locust distribution shows that vegetative regeneration by stool stumps or root suckers (mostly for old stands) are common.

Artificial regeneration by seedling was observed in young stands (age 6-10 years) and show us that black locust is still established in this area even the sites are improper for this species. Natural regeneration by seeds was also reported. A registration error or a particular case? It is well known that in our country this kind of regeneration was reported in very few cases (Negulescu and Săvulescu, 1957; Stănescu, 1979; Nicolescu et al., 2019).

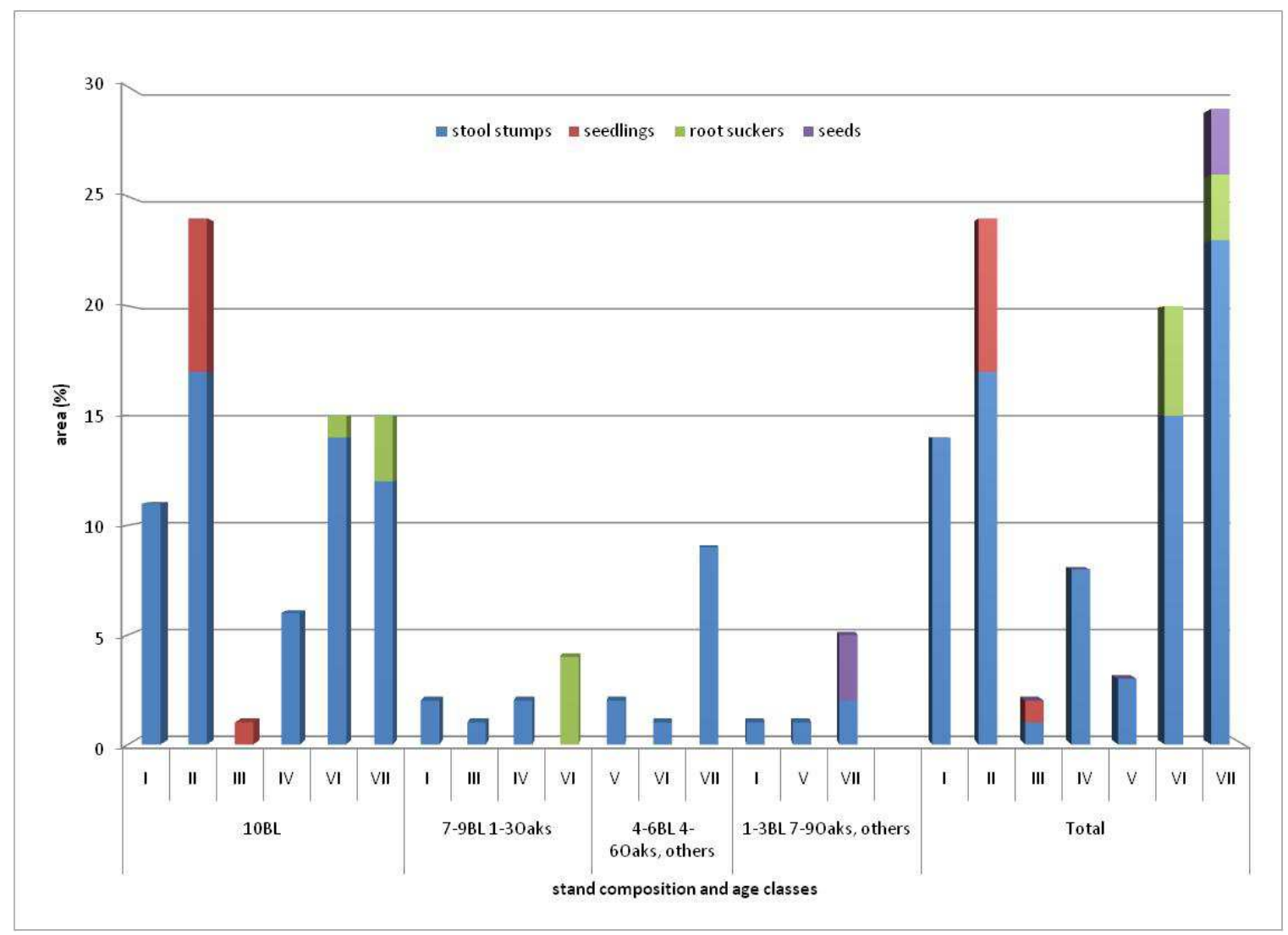

Figure 3. Black locust distribution according to stand composition and age classes

Black locust forests provide wood production and protection functions, so the volume is important. The data presented in figure 4 shows a comparative analysis between real stands volume (minimum and maximum) and the volume from the yield tables (Giurgiu and Drăghiciu, 2004).

The value of the volume in both, generative and vegetative regeneration pathway, are lower than the value from the Romanian yield table. Young stands (the third age classes) from medium quality sites, for example, have a volume between 38 to $89 \mathrm{~cm}$ ha-1 in the case of vegetative regeneration and $50 \mathrm{~cm}$ ha- 1 in case of generative regeneration. The yield table volume is $112 \mathrm{~cm}$ ha-1 (vegetative regeneration) and $116 \mathrm{~cm}$ ha-1 (generative regeneration). In old stands (the seventh age classes), the differences are much higher. The volume varies from 44 to $153 \mathrm{~cm}$ ha- 1 for vegetative regeneration and it is $241 \mathrm{~cm}$ ha-1 for generative regeneration. The yield table differences are also 


\section{Current Trends in Natural Sciences}

Vol. 9, Issue 17, pp. 126-131, 2020

https://doi.org/10.47068/ctns.2020.v9i17.014

Current Trends in Natural Sciences (on-line)

ISSN: 2284-953X

Current Trends in Natural Sciences (CD-Rom)

ISSN: 2284-9521

ISSN-L: 2284-9521

ISSN-L: 2284-9521

higher, from 250 to $333 \mathrm{~cm}$ ha-1. This is because the sites are unsuitable for black locust, one of the most important limitative factors is the high percentage of clay. There is one exception, a stand on aluviosol where the volume is a little higher than yield table.

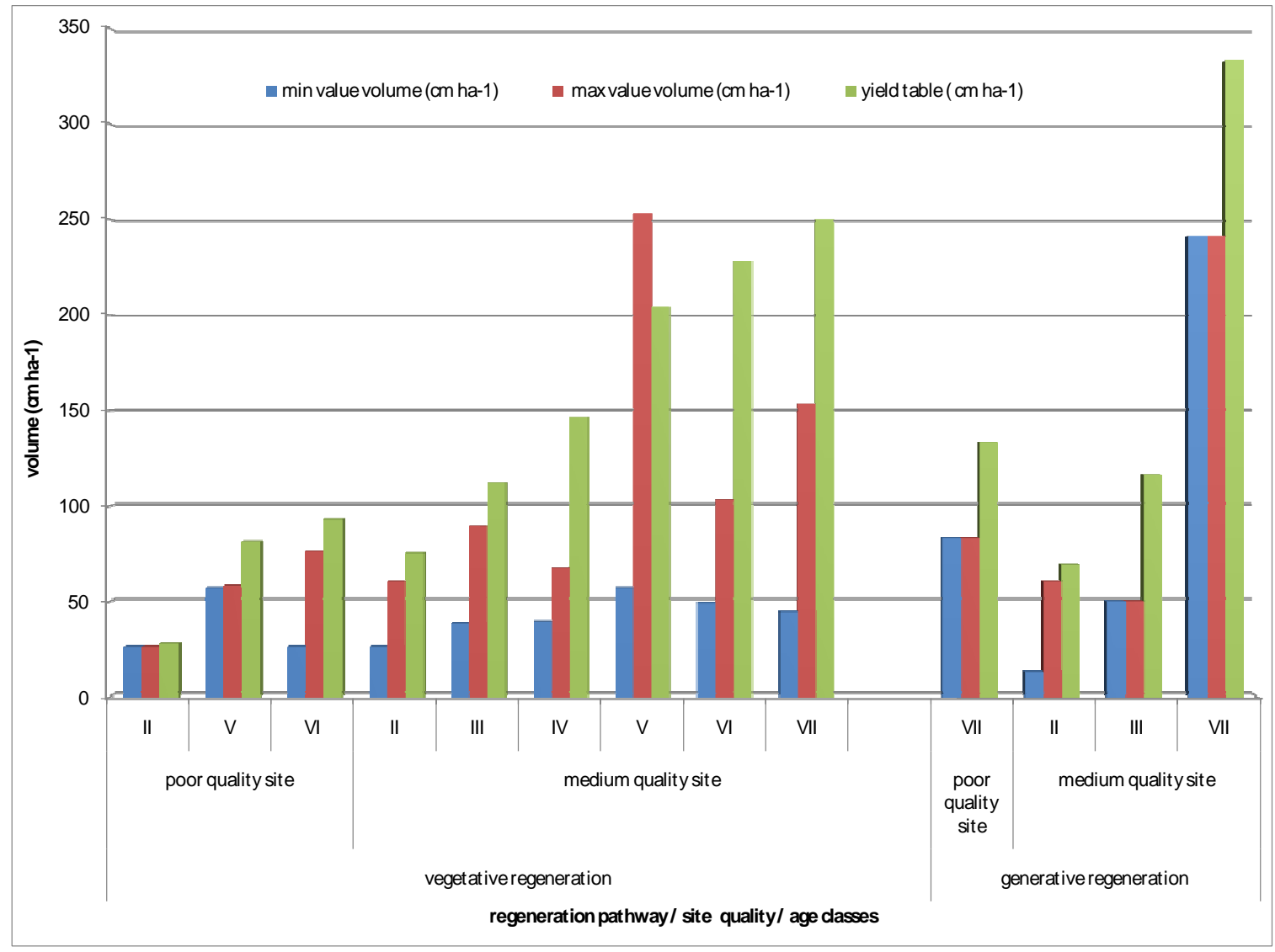

Figure 4. Black locust volume according to regeneration pathway, site quality and age classes

\section{CONCLUSIONS}

This paper shows the potential of black locust established in unsuitable site conditions, soil with high clay content.

Introduced in oaks species areal, black locust is found in pure but also in mixed stands.

The growing potential is lower than the national average for most cases. The highest potential was found in pure stands on aluviosol.

In terms of black locust volume on sandy soil, the results in our country are very good. This analysis showed us that it is not the same in specific conditions from the studied area.

\section{REFERENCES}

Anonymous. (2008). Amenajamentul Unității de producție Războinicu, Ocolul Silvic Strahaia [Plan Management Working Circle Războinicu, Forest District Strehaia].

Drăcea, M. (1928). Contribuții la cunoaşterea salcâmului în România cu privire specială asupra culturii sale pe solurile nisipoase din Oltenia [Contribution to the knowledge of black locust in Romania, with special emphasis on its culture on sandy soils of Oltenia]. Editura Tehnică Silvică, 92 p. 


\section{Current Trends in Natural Sciences}

Vol. 9, Issue 17, pp. 126-131, 2020

https://doi.org/10.47068/ctns.2020.v9i17.014

Current Trends in Natural Sciences (on-line)

ISSN: 2284-953X

Current Trends in Natural Sciences (CD-Rom)

ISSN: 2284-9521

ISSN-L: 2284-9521 ISSN-L: 2284-9521

Enescu, C.M., Dănescu, A. (2015). Black locust (Robinia pseudoacacia L.)—an invasive neophyte in the conventional land reclamation flora in Romania. Bull Trans Univ Braşov Ser II For Wood Ind Agric Food Eng 6, $23-30$.

Giurgiu, V., Drăghiciu, D. (2004). Modele matematico-auxologice şi tabele de producție pentru arborete [Mathematicalgrowth models and yield tables of stands]. Editura Ceres, Bucureşti, 607 p.

Haralamb, At. (1967). Cultura speciilor forestiere [Culture of tree species]. Editura Agro-Silvica, 755 p.

Negulescu, E., Săvulescu, Al. (1957). Dendrologie [Dendrology]. Editura Agro-Silvică de Stat, Bucureşti, Romania, $457 \mathrm{p}$

Negulescu, E., Săvulescu, Al. (1965). Dendrologie [Dendrology]. Editura Agro-Silvica, 511 p.

Nicolescu, V.N., Buzatu-Goanță, C., Bartlett, D., Iacob, N. (2019). Regeneration and Early Tending of Black Locust

(Robinia pseudoacacia L.) Stands in the North-West of Romania. SEEFOR 10 (2), 97-105.

Rédei, K., Veperdi, I. (2009). The role of black locust (Robinia pseudoacacia L.) in establishment of short-rotation energy plantations in Hungary. Int J Hort Sci 3, 41-44

Rédei, K., Csiha, I., Keserü, Z. (2011). Black locust (Robinia pseudoacacia L.) short-rotation crops under marginal site conditions. Act Silv Lign Hun 7, 125-132

Stănescu, V. (1979). Dendrologie [Dendrology]. Editura Didactică şi Pedagogică, Bucureşti, 470 p.

Vítková, M.; Conedera, M.; Sádlo, J.; Pergl, J.; Pyšek, P. (2018). Gefährlich und nützlich zugleich: Strategien zum anagement der invasiven Robinie [Dangerous and useful at the same time: strategies for the management of invasive Robinia].

Schweizerische Zeitschrift für Forstwesen, 169 (2), 77-85. Retrieved April 27, 2020, from

https://www.waldwissen.net/waldwirtschaft/schaden/invasive/wsl management robinie/index EN

https://www.google.ro/maps/ 